\title{
PENGARUH KOMPETENSI, INDEPENDENSI, DAN ETIKA TERHADAP KUALITAS AUDITOR PADA APARAT INSPEKTORAT DALAM PENGAWASAN PENGELOLAAN KEUANGAN DAERAH KOTA BITUNG
}

\author{
Lidya Anggiline Maramis \\ Heince Wokas
}

\begin{abstract}
The increasing demands of the community for clean governance, fair, transparent, and accountable should be taken seriously and systematically. All levels of state officials, both at the level of the executive, legislative, and judicial branches must have a shared commitment to uphold good governance and clean government. The study was conducted in the supervision of Government Internal City officials in this regard Inspectorate Bitung in Bitung City. In the present study investigated the influence of competence, independence and ethics for auditors in monitoring the quality of financial management. The purpose of research is to determine how much influence the competence, independence, and ethics to the quality of the personnel inspectorate auditors in financial management oversight Bitung City.

Data analysis methods used are descriptive statistics, the classical assumption test, test correlation coefficient, coefficient of determination test, hypothesis testing (test $f$ and $t$ test). to complete the overall data analysis used SPSS software version 20. The results showed the equation $Y=6.882-0.019+0.437 X 10.300 X 2+X 3$. Of multiple linear regression equation shows a constant value of 6.882 gives the sense that if competence (X1), independence (X2), and ethics (X3) constant perceived or equal to zero (0), then the magnitude of the variable quality of the auditor on the apparatus inspectorate $(Y)$ amounted to 6.882. Correlation coefficient obtained for the coefficient of determination of 0.700 and 0.490 , while the remaining 51\% of other variables not examined in this study. Results of hypothesis testing (test f) indicates the level of significance is less than 0.05 is 0.000 thus, the study received HA4 hypothesis, and hypothesis testing (t test) showed for the variable $(X 1)=0.864$ competence as such, this study rejected Hal hypothesis which states that competency variable does not affect the quality of the auditors, it can be seen from a greater significance level of 0.05 is 0.864 . These results contrast with previous research that states that affect the quality of the auditor's competence. This is due to the lack of training in research or no education system appropriate competency and followed by the Inspectorate in the auditor oversight of financial management in the city of Bitung, $(X 2)=0.05$ ie 0.001 independence as such, this study received a hypothesis Ha2, and $(X 3)=0.05$ ie 0.008 ethics as such, this study received Ha3 hypothesis.
\end{abstract}




\section{PENDAHULUAN}

Kondisi saat ini, masih ada daerah dalam penyelenggaraan pemerintahannya yang belum siap dengan sistem pemerintahan yang baru untuk menyelenggarakan pemerintahan daerah sesuai dengan tata kelola pemerintahan yang baik. Banyak terjadi kasus di sejumlah daerah yang berkaitan dengan masalah korupsi, ketidakberesan, penyalahgunaan wewenang dan jabatan, pelanggaran, dan masih banyak lagi kasus pidana lainnya.

Mengapa hal ini terjadi? Lemahnya pengendalian internal dalam penyelenggaraan pemerintahan daerah merupakan salah satu penyebab terjadinya ketidakefisienan dan ketidakefektifan penyelenggaraan pemerintahan daerah dan tentunya berdampak pada pemborosan anggaran dan keuangan daerah. Disamping itu, akibat lemahnya pengendalian internal dalam penyelenggaraan pemerintahan daerah, ada sebagian oknum di lingkungan pemerintahan daerah yang tidak atau belum siap dengan berlakunya otonomi daerah, terutama berkaitan dengan masalah etika dan moral dari oknum pejabat pemerintahan daerah tersebut yang rendah. Disisi lain, masih menjadi tanda tanya besar di kalangan profesi audit internal mengenai sejauh mana peran serta dari fungsi pengawasan termasuk para pejabat pengawas yang berada di lingkungan fungsi pengawasan atau inspektorat daerah baik tingkat provinsi, kabupaten, maupun kota, terutama dalam upaya untuk mengawal berbagai kegiatan dan program pemerintah daerah dalam penyelenggaraan pemerintahan daerah yang memenuhi prinsip tata kelola pemerintahan daerah yang baik dan dapat dipertanggungjawabkan.

Badan Pengawas Daerah atau yang sekarang ini lebih dipopulerkan dengan sebutan Inspektorat Provinsi/Kabupaten/Kota (selanjutnya disingkat dengan Inspektorat) merupakan suatu lembaga pengawasan di lingkungan pemerintahan daerah, baik untuk tingkat provinsi, kabupaten, atau kota, memainkan peran yang sangat penting dan signifikan untuk kemajuan dan keberhasilan pemerintah daerah dan perangkat daerah di lingkungan pemerintahan daerah dalam menyelenggarakan pemerintahan di daerah dan mencapai tujuan dan sasaran yang telah ditetapkan.

Dalam penelitian ini penulis menentukan obyek penelitian yaitu pemerintahan Kota Bitung. Alasan penulis memilih pemerintah Kota Bitung karena pertumbuhan serta perkembangan ekonomi didaerah ini secara umum cukup menjanjikan dan menarik untuk dilakukan penelitian. Sekitar tahun 2008 Kota Bitung mengalami perubahan besar baik dari sektor sumber daya alam (SDA) maupun sumber daya Manusia (SDM) maupun penataan kotanya dari beberapa sektor yang menguntungkan daerah ini hingga tahun 2012 ini banyak prestasi, penghargaan yang diraih oleh Kota Bitung terlebih hasil pemeriksaan dari Badan Pemeriksaan keuangan (BPK) yang mendapatkan hasil yang memuaskan untuk kota ini.

Data kuantitatif adalah data yang disajikan dan diukur dalam bentuk skalanumeric atau angkaangka.Dalam hal ini merupakan pengukuran terhadap variable kompetensi (X1), independensi (X2), dan etika (X3) terhadap kualitas auditor pada aparat inspektorat Kota Bitung (Y).Data kualitatif, adalah data yang bersifat deskriptif atau berbentuk uraian-uraian atau penjelasan serta tidak diukur dalam skala numeric.

\section{LANDASAN TEORI}

\subsection{Pengertian Akuntansi Pemerintahan}

Revrisond baswir (1998:12) "Akuntansi pemerintahan (termasuk didalamnya akuntansi untuk lembaga-lembaga yang tidak bertujuan untuk mendapatkan atau mencari laba), adalah bidang akuntansi yang berkaitan dengan lembaga pemerintahan yang tidak bertujuan untuk mencarilaba".

Dari definisi diatas dapat ditarik kesimpulan bahwa akuntansi pemerintahan juga mempunyai pengawasan dalam pengelolaan keuangan daerah dengan memberikan informasi pada para pengambil keputusan dalam suatu entitas yang berlandaskan kompetensi, independensi, serta motivasi.

\subsubsection{Pengelolaan Keuangan Daerah}

Keuangan daerah dapat diartikan sebagai " semua hak dan kewajiban yang dapat dinilai dengan uang, juga segala satuan, baik dalam berupa uang atau barang, yang dapat dijadikan kekayaan daerah 
sepanjang belum dimiliki/dikuasai oleh negara atau daerah yang lebih tinggi serta pihak-pihak lain yang sesuai ketentuan/ peraturan perundangan yang berlaku (Abdul Halim2007:23).

\subsubsection{Pengawasan intern pemerintah}

Pengawasan atas penyelenggaraan pemerintahan diperlukan untuk menjamin agar pelaksanaan kegiatan pemerintahan berjalan sesuai dengan rencana dan sesuai dengan ketentuan peraturan perundang-undangan yang berlaku. Selain itu, dalam rangka mewujudkan good governance dan clean government, pengawasan juga diperlukan untuk mendukung penyelenggaraan pemerintahan yang efektif dan efisien, transparan, akuntabel, serta bersih dan bebas dari praktik-praktik KKN. Pengawasan terhadap penyelenggaran pemerintahan tersebut dapat dilakukan melalui pengawasan melekat, pengawasan masyarakat, dan pengawasan fungsional.

Aparat pengawasan intern pemerintah terdiri atas :

1) BPKP;

2) Inspektorat Jenderal atau nama lain yang secara fungsional melaksanakan pengawasan intern;

3) Inspektorat provinsi; dan

4) Inspektorat Kabupaten/Kota

\subsubsection{Audit dan Akuntabilitas Pengelolaan Keuangan Daerah}

Salah satu bagian yang harus direformasi mengikuti paradigma baru tersebut adalah sitem pengelolaan dan pengawasan keuangan daerah. Sistem lemah dalam masa orde baru harus direformasi agar terciptanya transparansi dan akuntabilitas penyelenggaraan keuangan daerah. Sistem pengawasan pengelolaan keuangan daerah yang baru diharapkan akan mampu mencegah atau menghindari adanya penyimpangan-penyimpangan yang akan mengganggu proses kegiatan dalam pengelolaan keuangan daerah.

\subsection{Pengertian Audit}

Nurlan Darise (2009: 310) audit adalah proses identifikasi masalah, analisis, dan evaluasi bukti yang dilakukan secara independen, obyektif dan professional berdasarkan standar audi, untuk menilai kebenaran, kecermatan, kredibilitas, efektivitas, efisien dan keandalan informasi pelaksanaan tugas dan fungsi instansi pemerintah.

\subsubsection{Perencanaan Audit Sektor Publik}

Pada Audit Sektor Publik, Perencanaan merupakan tahap yang vital dalam audit meliputi tahap - tahap yakni:

(1) Pemahaman atas sistem akuntansi keuangan sektor publik,

(2) Penentuan tujuan dan lingkup audit yang ditetapkan sesuai dengan mandat dan wewenang lembaga audit dan pengawas,

(3) Penilaian resiko atas resiko pengendalian, resiko bawaan, resiko deteksi.

(4) Penyusunan rencana audit,

(5) Penyusunan program audit

\subsubsection{Pelaksanaan Audit Sektor Publik}

Dalam pelaksanaan audit sektor publik, terdapat definisi struktur pengendalian internal. Ada 3 golongan tujuan yang terdiri atas

(1) Keandalan laporan keuangan,

(2) Kepatuhan terhadap hukum dan peraturan yang berlaku dan

(3) Efektivitas dan efisiensi operasi. Pada jenis pengendalian internal juga meliputi atas organisasi, pemisahan tugas, fisik, persetujuan dan otorisasi, akuntansi, personel, supervisi dan manajemen

\subsubsection{Proses Audit Sektor Publik}

Langkah - langkah dalam proses audit (Indra Bastian,2001) adalah :

(1) Perencanaan (PLANNING) yang di dalamnya meliputi (a) Deskripsi system akuntansi keuangan sektor publik, (b) Menyusun tujuan dan lingkup audit, (c) Menilai resiko, (d) Rencana audit

(2) Pelaksanaan (EXECUTING) yang di dalamnya meliputi (a) Mengembangkan program audit, (b) Sistem pengendalian internal, (c) Melakukan pengujian prosedur analitik pengujian substantif (jika 
buruk), (d) Melakukan pengujian bersandar pada pengendalian internal pengujian substantif (jika baik)

(3) Pelaporan (REPORTING) yang di dalamnya meliputi (a) Review kertas kerja dan kesimpulan, (b) Analisis hasil audit, (c) Laporan audit dan LHP bawasda pemda

\subsubsection{Pelaporan}

Pada tahapan akhir dari audit sektor publik yakni pelaporan, pada pelaporan ini, perlu diperhatikan beberapa item diantaranya yakni

(1) Tinjauan kertas kerja dan kesimpulan. Kertas kerja merupakan media penghubung antara catatan klien dengan laporan audit. Kepemilikan kertas kerja sepenuhnya ada ditangan auditor

(2) Kertas kerja dan standar pelaporan. Kertas kerja berhubungan erat dengan standar pelaporan dimana diperlukan untuk berjaga-jaga terhadap tuntutan pemakai laporan keuangan dan sanksi lembaga profesi.

(3) Isi kertas kerja. Kertas kerja merupakan bukti dilaksanakannya standar auditing dan program audit yang telah ditetapkan.

\subsection{Kualitas Auditor}

Sampai saat ini belum ada definisi yang pasti mengenai apa dan bagaimana kualitas audit yang baik itu. Tidak mudah untuk menggambarkan dan mengukur kualitas audit secara obyektif dengan beberapa indikator. Hal ini dikarenakan kualitas audit merupakan sebuah konsep yang kompleks dan sulit dipahami, sehingga sering kali terdapat kesalahan dalam menentukan sifat dan kualitasnya. Hal ini terbukti dari banyaknya penelitian yang menggunakan dimensi kualitas audit yang berbeda-beda.

Audit yang berkualitas adalah audit yang dapat ditindaklanjuti oleh audite. Kualitas ini harus dibangun sejak awal pelaksanaan audit hingga pelaporan dan pemberian rekomendasi. Dengan demikian, indikator yang digunakan untuk mengukur kualitas audit antara lain kualitas proses, apakah audit dilakukan dengan cermat, sesuai prosedur, sambil terus mempertahankan sikap skeptis.

Dari pengertian tentang kualitas audit di atas maka dapat disimpulkan bahwa kualitas audit merupakan segala kemungkinan (probability) dimana auditor pada saat mengaudit laporan keuangan klien dapat menemukan pelanggaran yang terjadi dalam sistem akuntansi klien dan melaporkannya dalam laporan keuangan auditan, dimana dalam melaksanakan tugasnya tersebut auditor berpedoman pada standar auditing dan kode etik akuntan publik yang relevan.

\subsubsection{Kompetensi}

Sri Lastanti (2005) mendefinisikan kompetensi sebagai ketrampilan dari seorang ahli. Dimana ahli didefinisikan sebagai seseorang yang memiliki tingkat ketrampilan tertentu atau pengetahuan yang tinggi dalam subyek tertentu yang diperoleh dari pelatihan dan pengalaman dan juga mendefinisikan bahwa seorang yang berkompeten adalah orang yang dengan ketrampilannya mengerjakan pekerjaan dengan mudah, cepat, intuitif dan sangat jarang atau tidak pernah membuat kesalahan.

Berdasarkan uraian di atas dapat ditarik kesimpulan bahwa kompetensi auditor adalah pengetahuan, keahlian, dan pengalaman yang dibutuhkan auditor untuk dapat melakukan audit secara objektif, cermat dan seksama. Hayes-Roth mendefinisikan keahlian sebagai pengetahuan tentang suatu lingkungan tertentu, pemahaman terhadap masalah yang timbul dari lingkungan tersebut, dan keterampilan untuk memecahkan permasalahan tersebut.

\subsubsection{Independensi}

Auditor harus memiliki sikap yang netral dan tidak bias serta menghindari konflik kepentingan dalam merencanakan, melaksanakan dan melaporkan pekerjaan yang dilakukannya. Auditor harus objektif dalam melaksanakan audit. Prinsip objektifitas mensyaratkan agar auditor dalam melaksanakan audit dengan jujur dan tidak mengkompromikan kualitas. Pimpinan APIP tidak diperkenankan menempatkan auditor dalam situasi yang membuat auditor tidak mampu mengambil keputusan berdasarkan pertimbangan profesionalnya. 


\subsubsection{Etika}

Auditor harus mematuhi kode etik yang ditetapkan. Pelaksanaan audit harus mengacu pada standar audit ini, dan auditor wajib mematuhi kode etik yang merupakan bagian yang tidak terpisahkan dari standar audit. Kode etika ini dibuat bertujuan untuk mengatur hubungan antara :

(1) Auditor dengan rekan sekerjanya,

(2) Auditor dengan atasannya, dan

(3) Auditor dengan auditan (objek pemeriksanya) serta

(4) Auditor dengan masyarakat.

\section{GAMBARAN UMUM OBYEK PENELITIAN}

Pelaksanaan kegiatan pengawasan oleh inspektorat dikoordinasikan olehKepala Inspektorat. Dalam Peraturan Menteri Dalam Negeri (Permendagri) No. 23 Tahun 2007, Kepala Inspektorat, baik di tingkat provinsi, kabupaten, dan kota disebut dengan Inspektur Provinsi, dan Inspektur Kabupaten/Kota.

Kegiatan yang dilakukan oleh inspektorat adalah kegiatan pemeriksaan (audit), yang meliputi:

1. Pemeriksaan secara berkala dan komprehensif terhadap kelembagaan, pegawai daerah, keuangan daerah, barang daerah, dan urusan pemerintahan.

2. Pemeriksaan dana dekonsentrasi.

3. Pemeriksaan tugas pembantuan.

4. Pemeriksanaan terhadap kebijakan pinjaman dan hibah luar negeri. Selain pemeriksaan tersebut, auditor Inspektorat dapat juga melakukan pemeriksaan tertentu dan pemeriksaan terhadap laporan mengenai indikasi kemungkinan terjadinya tindak penyimpangan, korupsi, kolusi, dan nepotisme di dalam penyelenggaraan pemerintahan daerah. Pelaksanaan kegiatan pengawasan ini dikoordinasikan oleh Kepala Inspektorat, yang dengan Peraturan Menteri Dalam Negeri (Permendagri) No. 23 Tahun 2007, kepala Inspektorat, baik ditingkat provinsi, kabupaten, dan kota disebut dengan Inspektur Jenderal, Inspektur Provinsi, dan Inspektur Kabupaten/Kota.

\section{ANALISIS DAN EVALUASI}

\subsection{Hasil Penelitian}

Tabel 4.1

Komposisi Responden Berdasarkan Jenis Kelamin

\begin{tabular}{|c|c|c|}
\hline Jenis Kelamin & Jumlah & Presentase \\
\hline Pria & 17 Orang & $40 \%$ \\
\hline Wanita & 25 Orang & $60 \%$ \\
\hline Jumlah & 42 Orang & $100 \%$ \\
\hline
\end{tabular}

Sumber: Data Olahan Tahun 2012

Tabel 4.2

Komposisi Responden Berdasarkan Tingkat Pendidikan

\begin{tabular}{|c|c|c|}
\hline $\begin{array}{c}\text { Tingkat } \\
\text { Pendidikan }\end{array}$ & Jumlah & Presentase \\
\hline Magister (S2) & 4 & $9 \%$ \\
\hline Sarjana (S1) & 24 & $57 \%$ \\
\hline Diploma & 2 & $5 \%$ \\
\hline SLTA/SMA & 12 & $29 \%$ \\
\hline Jumlah & 42 Orang & $100 \%$ \\
\hline
\end{tabular}

Sumber: Data Olahan Tahun 2012 


\subsection{Uji Asumsi Klasik}

\subsubsection{Uji Normalitas}

Uji normalitas dalam penelitian ini menggunakan uji One Sample Kolmogorov-Smirnov melalui SPSS versi 20 dengan menggunakan taraf signifikansi 0.05. Data dinyatakan berdistribusi normal jika signifikansi lebih besar dari $5 \%$ atau 0.05 .

\section{Gambar 4.1 Uji Normalitas}

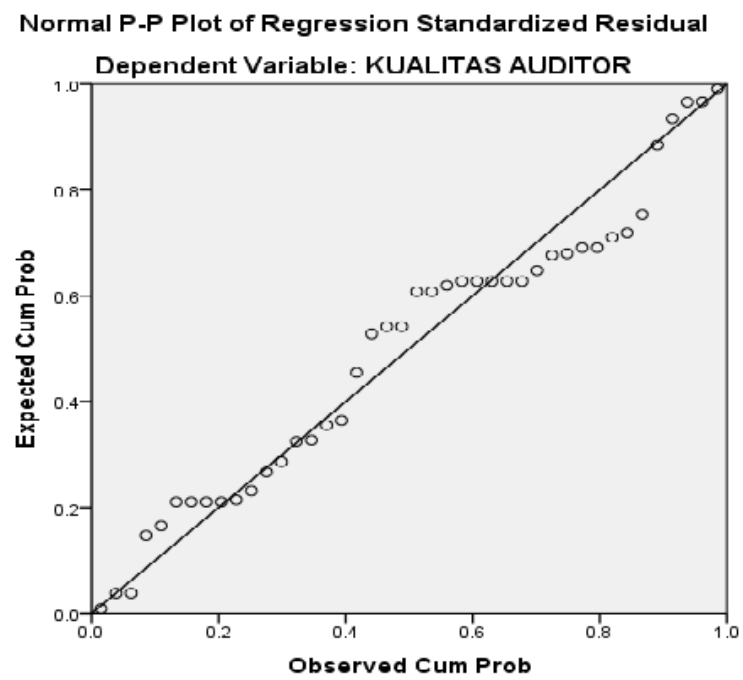

Sumber : Output Pengolahan Data SPSS, 2012

Dari gambar diatas dapat dilihat bahwa data menyebar di sekitar garisdiagonal dan mengikuti arah garis diagonal, maka data terdistribusi dengan normal dan model regresi telah memenuhi asumsi normalitas.

\subsubsection{Uji Multikoliniearitas}

Untuk mendeteksi ada tidaknya multikolinearitas dengan melihat nilai tolerance dan VIF. Semakin kecil nilai Tolerance dan semakin besar nilai VIF maka senakin mendekati terjadinya masalah multikolinearitas. Nilai cut off yang umum dipakai untuk menunjukan adanya multikolinearitas adalah nilai tolerance $>0,10$ atau nilai $\mathrm{VIF}<10$.

Tabel 4.12

Hasil Uji Multikolinearitas

Coefficients $^{\mathrm{a}}$

\begin{tabular}{|c|c|c|}
\hline \multirow[t]{2}{*}{ Model } & \multicolumn{2}{|c|}{ Collinearity Statistics } \\
\hline & Tolerance & VIF \\
\hline (Constant) & & \\
\hline KOMPETENSI & .739 & 1.353 \\
\hline INDEPENDENSI & .819 & 1.221 \\
\hline ETIKA & .722 & 1.385 \\
\hline
\end{tabular}

Sumber: Output Pengolahan Data SPSS, 2012

Dari tabel 4.12 terlihat bahwa tidak ada variabel bebas yang memilki nilai tolerance kurang dari 0,10 . Hasil uji VIF juga menunjukan hal yang sama yaitu tidak ada satupun variabel independen yang memiliki VIF lebih dari 10. Sehingga dapat disimpulkan bahwa tidak terjadi multikolinearitas antar variabel bebas dalam persamaan regresi. 


\subsubsection{Uji Heteroskedastisitas}

Untuk mendeteksi ada tidaknya heteroskedastisitas, dapat dilakukan dengan melihat ada atau tidaknya pola tertentu pada grafik Scatter Plot. Jika grafik Scatter Plot tidak membentuk atau menggambarkan pola tertentu, berarti dapat dikatakan model regresi terbebas dari heteroskedastisitas.

Gambar 4.2

Hasil Uji Heteroskedastisitas

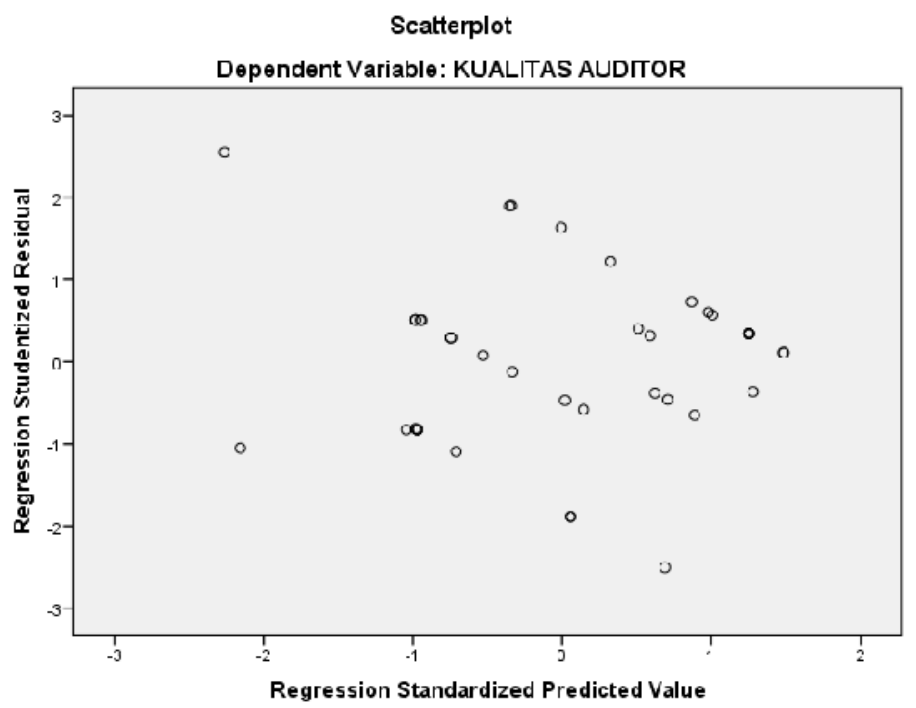

Sumber : Output Pengolahan Data SPSS, 2012

Dari gambar diatas terlihat bahwa dalam persamaan regresi ini tidak terdapat heteroskedastisitas. Hal ini terlihat dari penyebaran titik-titik yang tdak memiliki pola yang jelas, serta titik-titik tersebut menyebar di atas dan dibawah angka 0 pada sumbu $Y$, sehingga tidak terjadi heteroskedastisitas dalam persamaan ini

\subsubsection{Uji Autokorelasi}

Tabel 4.13

Hasil Uji Autokorelasi

Model Summary ${ }^{b}$

\begin{tabular}{|l|r|r|r|r|r|}
\hline Model & R & R Square & $\begin{array}{c}\text { Adjusted R } \\
\text { Square }\end{array}$ & $\begin{array}{c}\text { Std. Error of } \\
\text { the Estimate }\end{array}$ & $\begin{array}{c}\text { Durbin- } \\
\text { Watson }\end{array}$ \\
\hline 1 & $.700^{\mathrm{a}}$ & .490 & .450 & 1.55143 & 1.648 \\
\hline
\end{tabular}

Sumber : Output Pengolahan Data SPSS, 2012

Dari pengujian Durbin-Watson dalam penelitian ini dihasilkan nilai DW sebesar 1,648. Nilai ini dibandingkan dengan nilai tabel menggunakan signifikasi 5\%, jumlah data 42 (n) dan jumlah variabel independen $3(\mathrm{k}=3)$, maka terletak diantara batas atas $(\mathrm{du}=1,6017)$ dan batas bawah $(\mathrm{dl}=1,357)$. Oleh karena nilai DW 1,648 lebih besar dari batas atas (du) 1,6017 dan kurang dari 2,3383 (4-du) maka dapat disimpulkan bahwa dalam persamaan regresi ini tidak terdapat autokorelasi

\subsection{Analisis Regresi Linear Berganda}

Berdasarkan hasil perhitungan dan pengolahan data menggunakan program SPSS, maka hasil perhitungan dan persamaan regresi linear berganda dalam penelitian ini dapat dilihat pada tabel 4.14. 
Tabel 4.14

Regresi Liner berganda

\begin{tabular}{|l|r|r|r|r|r|}
\hline Model & \multicolumn{2}{|c|}{$\begin{array}{c}\text { Unstandardized } \\
\text { Coefficients }\end{array}$} & $\begin{array}{c}\text { Standardize } \\
\mathrm{d} \\
\text { Coefficients }\end{array}$ & $\mathrm{t}$ & Sig. \\
\cline { 2 - 5 } & \multicolumn{1}{|c|}{$\mathrm{B}$} & Std. Error & \multicolumn{1}{c|}{ Beta } & & \\
\hline (Constant) & 6.882 & 2.778 & & 2.477 & .018 \\
KOMPETENSI & -.019 & .109 & -.023 & -.173 & .864 \\
1 INDEPENDENSI & .437 & .118 & .473 & 3.694 & .001 \\
ETIKA & .300 & .107 & .381 & 2.796 & .008 \\
\hline
\end{tabular}

Sumber : Output Pengolahan Data SPSS, 2012

Berdasarkan tabel diatas, apabila diperlihatkan dalam modal persamaan statistik diperoleh model persamaan regresi sebagai berikut :

$$
\begin{gathered}
Y=\alpha+\beta 1 X 1+\beta 2 X 2+\beta 3 X 3 \\
Y=6,882-0,019 X_{1}+0,437 X_{2}+0,300 X_{3}+\varepsilon
\end{gathered}
$$

Untuk kompetensi menunjukan hasil negatif, untuk itu kompetensi tidak searah dengan kualitas auditor atau dengan kata lain kompetensi yang baik akan berpengaruh terhadap kualitas auditor yang baik pula, demikian sebaliknya bila kompetensi rendah/buruk maka kualitas auditor akan rendah/buruk. Pengaruh signifikan menunjukkan bahwa kompetensi mempunyai peranan yang penting dalam meningkatkan kualitas auditor.

Pengaruh positif menunjukkan bahwa pengaruh etika adalah searah dengan kualitas auditor atau dengan kata lain keahlian yang baik/tinggi akan berpengaruh terhadap kualitas auditor yang baik/tinggi, demikian sebaliknya bila etika rendah/buruk maka kualitas auditor akan rendah/buruk. Pengaruh signifikan menunjukkan bahwa etika tidak mempunyai peranan yang signifikan/penting dalam meningkatkan kualitas auditor.

Pengaruh positif menunjukkan bahwa pengaruh independensi adalah searah dengan kualitas auditor atau dengan kata lain keahlian yang baik/tinggi akan berpengaruh terhadap kualitas auditor yang baik/tinggi, demikian sebaliknya bila independensi rendah/buruk maka kualitas auditor akan rendah/buruk. Pengaruh signifikan menunjukkan bahwa independensi mempunyai peranan yang penting dalam meningkatkan kualitas auditor.

Dalam hasil penelitian ini menunjukan Konstanta $\alpha$ sebesar 6,882 memberikan pengertian bahwa jika sikap kompetensi, independensi, dan etika yang dipersepsikan konstan atau sama dengan nol (0), maka besarnya variabel kualitas auditor (Y) sebesar 6,882

Selanjutnya nilai $\beta 1, \beta 2, \beta 3$ yang merupakan koefisien regresi dari variabel X1(Kompetensi), $\mathrm{X} 2$ (Independensi), dan X3(Etika) mempunyai arti bahwa jika variabel kompetensi, independensi, dan etika mengalami peningkatan 1\%, maka besarnya kualitas auditor (Y) juga akan mengalami kenaikan atau peningkatan sebesar 0,019, sebesar 0,437 dan sebesar 0,300 dengan asumsi variabel lainnya tetap atau konstan

Dengan demikian dapat diketahui bahwa terdapat hubungan yang tidak searah antara variabel bebas X1, X2, dan X3 dengan variabel terikat $\mathrm{Y}$ atau kualitas auditor dimana angka koefisien yang diperoleh variabel X1 kompetensi tidak mempengaruhi kualitas auditor dan menunjukan angka Negatif (-) berbeda dengan independensi dan etika. Berdasarkan nilai koefisien regresi tersebut, dapat diketahui pula bahwa ternyata pengaruh independensi mempunyai pengaruh yang lebih dominan terhadap kualitas auditor pada aparat inspektorat kota bitung 


\subsection{Pengujian Hipotesis}

\subsubsection{Koefisien Korelasi}

Tabel 4.15

Koefisien Korelasi

\begin{tabular}{|l|r|r|r|r|}
\hline Model & \multicolumn{1}{|c|}{$\mathrm{R}$} & R Square & $\begin{array}{c}\text { Adjusted R } \\
\text { Square }\end{array}$ & $\begin{array}{c}\text { Std. Error of } \\
\text { the Estimate }\end{array}$ \\
\hline 1 & $.700^{\mathrm{a}}$ & .490 & .450 & 1.55143 \\
\hline
\end{tabular}

Sumber : Output Pengolahan Data SPSS, 2012

Dapat dilihat bahwa koefisien korelasi linear nilai $\mathrm{R}$ yang diperoleh sebesar 0,700 Angka ini menunjukkan bahwa hubungan antara variabel bebas $(\mathrm{X})$ dengan variabel terikat $(\mathrm{Y})$ cukup kuat yaitu $0,70 \%$ serta angka korelasi yang dihasilkan menunjukkan angka positif $(+)$ yang berarti bahwa hubungan kedua variabel searah.

\subsubsection{Koefisien Determinasi $\left(R^{2}\right)$}

Tabel 4.16

Koefisien determinasi $\left(r^{2}\right)$

\begin{tabular}{|l|r|r|r|r|}
\hline Model & R & R Square & $\begin{array}{c}\text { Adjusted R } \\
\text { Square }\end{array}$ & $\begin{array}{c}\text { Std. Error of } \\
\text { the Estimate }\end{array}$ \\
\hline 1 & $.700^{\mathrm{a}}$ & .490 & .450 & 1.55143 \\
\hline
\end{tabular}

Sumber : Output Pengolahan Data SPSS, 2012

Dapat dilihat nilai $\mathrm{R}^{2}$ adalah sebesar 0,490 atau 49\%. Angka ini menunjukkan bahwa kualitas auditor sebesar .450 dipengaruhi oleh faktor-faktor kompetensi, independensi dan etika sebesar 49\% sedangkan sisanya sebesar $51 \%$ dijelaskan oleh factor-faktor lain atau variabel lain yang tidak diteliti dalam penelitian ini.

\subsubsection{Uji t Statistik}

Tabel 4.17

Uji t Statistik

\begin{tabular}{|l|r|r|r|r|r|}
\hline \multirow{2}{*}{ Model } & \multicolumn{2}{|c|}{$\begin{array}{c}\text { Unstandardized } \\
\text { Coefficients }\end{array}$} & $\begin{array}{c}\text { Standardized } \\
\text { Coefficients }\end{array}$ & \multirow{2}{*}{ T } & \multirow{2}{*}{ Sig. } \\
\cline { 2 - 5 } & \multicolumn{1}{|c|}{ B } & Std. Error & \multicolumn{1}{c|}{ Beta } & & \\
\hline (Constant) & 6.882 & 2.778 & & 2.477 & .018 \\
KOMPETENSI & -.019 & .109 & -.023 & -.173 & .864 \\
INDEPENDENSI & .437 & .118 & .473 & 3.694 & .001 \\
ETIKA & .300 & .107 & .381 & 2.796 & .008 \\
\hline
\end{tabular}

Sumber : Output Pengolahan Data SPSS, 2012

Variabel kompetensi tidak berpengaruh terhadap kualitas auditor, hal ini dapat dilihat dari tingkat signifikasi yang lebih besar dari 0,05 yaitu 0,864 dengan demikian, penelitian ini menolak hipotesis $\mathrm{H} 1$ yang menyatakan bahwa kompetensi berpengaruh terhadap kualitas auditor pada aparat Inspektorat dalam pengawasan pengelolaan keuangan daerah di kota Bitung dan Menerima Hipotesis $\mathrm{H}_{0} 1$ yang menyatakan bahwa kompetensi tidak berpengaruh terhadap kualitas auditor pada aparat Inspektorat dalam pengawasan pengelolaan keuangan daerah di kota Bitung

Variabel Independensi berpengaruh terhadap kualitas auditor, hal ini dapat dilihat dari tingkat signifikasi yang lebih kecil dari 0,05 yaitu 0,001 dengan demikian, penelitian ini menerima hipotesis H2 yang menyatakan bahwa independensi berpengaruh terhadap kualitas auditor pada aparat Inspektorat dalam pengawasan pengelolaan keuangan daerah di kota Bitung dan menolak Hipotesis 
$\mathrm{H}_{0} 2$ yang menyatakan bahwa independensi tidak berpengaruh terhadap kualitas auditor pada aparat Inspektorat dalam pengawasan pengelolaan keuangan daerah di kota Bitung

Variabel Etika berpengaruh terhadap kualitas auditor, hal ini dapat dilihat dari tingkat signifikasi yang lebih kecil dari 0,05 yaitu 0,008 dengan demikian, penelitian ini menerima hipotesis H3 yang menyatakan bahwa etika berpengaruh terhadap kualitas auditor pada aparat Inspektorat dalam pengawasan pengelolaan keuangan daerah di kota Bitung dan menolak Hipotesis $\mathrm{H}_{0} 3$ yang menyatakan bahwa etika tidak berpengaruh terhadap kualitas auditor pada aparat Inspektorat dalam pengawasan pengelolaan keuangan daerah di kota Bitung.

\subsubsection{Uji F statistik}

Tabel 4.18

Uji F Statistik

ANOVA ${ }^{a}$

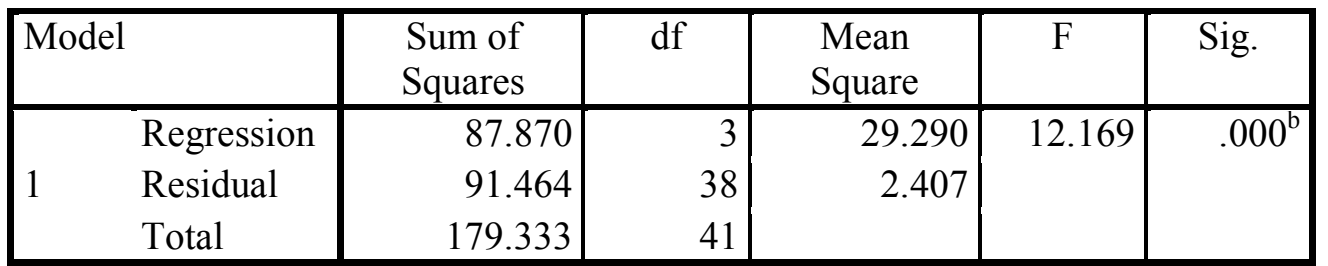

Sumber : Output Pengolahan Data SPSS, 2012

Berdasarkan table 4.18 diatas, secara bersama-sama Variabel kompetensi, Independensi, dan etika berpengaruh terhadap kualitas auditor, hal ini dapat dilihat dari tingkat signifikasi yang lebih kecil dari 0,05 yaitu 0,000 dengan demikian, penelitian ini menerima hipotesis $\mathrm{H} 4$ yang menyatakan bahwa kompetensi, independensi dan etika berpengaruh terhadap kualitas auditor pada aparat Inspektorat dalam pengawasan pengelolaan keuangan daerah di kota Bitung dan menolak Hipotesis $\mathrm{H}_{0} 4$ yang menyatakan bahwa kompetensi, independensi dan etika tidak berpengaruh terhadap kualitas auditor pada aparat Inspektorat dalam pengawasan pengelolaan keuangan daerah di kota Bitung

\subsection{Pembahasan}

Dalam penelitian ini didapatkan hasil bahwa variabel kompetensi tidak berpengaruh terhadap kualitas auditor, hal ini dapat dilihat dari tingkat signifikasi dengan hasil negatif (-) pada pengujian regresi linear berganda. Hasil ini bertolak belakang dengan hasil penelitian sebelumnya yang menyatakan bahwa kompetensi berpengaruh terhadap kualitas auditor. Hal ini diakibatkan oleh situasi yang ada dengan tidak adanya perhatian dari pemerintah dengan kualitas auditor sehingga kurangnya pelatihan, kemampuan/pemahaman, pengetahuan yang tinggi, bahkan keterampilan serta tidak mengukur sejauh mana kompetensi yang dimiliki oleh auditor pada aparat Inspektorat dalam pengawasan pengelolaan keuangan daerah di kota Bitung

Variabel independensi berpengaruh terhadap kualitas auditor, hal ini dapat dilihat dari tingkat signifikasi yang lebih dominan.Dengan situasi yang ada pada inspektorat Kota Bitung para auditor memiliki sikap yang netral dan tidak bias dan juga dituntut harus memiliki kemampuan dalam mengumpulkan setiap informasi yang dibutuhkan dalam pengambilan keputusan audit dimana hal tersebut harus didukung dengan sikap independendan juga menghindari konflik kepentingan dalam merencanakan, melaksanakan audit. Tidak dapat dipungkiri bahwa sikap independen merupakan hal yang melekat pada diri auditor, sehingga independen seperti telah menjadi syarat mutlak yang harus dimiliki.

Untuk variabel etika menunjukan berpengaruh terhadap kualitas auditor, hal ini dapat dilihat dari tingkat signifikasi yang menunjukan dengan situsi yang ada. Sebagai seorang auditor, etika professional memang harus selalu dipegang teguh agar dapat menjalankan tugas sesuai dengan tuntutan profesi. 


\section{PENUTUP}

\subsection{Kesimpulan}

Kualitas auditor adalah probabilitas seorang auditor atau akuntan pemeriksa menemukan penyelewengan dalam sistem akuntansi suatu unit atau lembaga, kemudian melaporkannya dalam laporan audit. berikut:

Berdasarkan penelitian yang telah dilakukan maka dapat disimpulkan beberapa hal sebagai

1. Variabel kompetensi tidak berpengaruh terhadap kualitas auditor, hal ini dapat dilihat dari tingkat signifikasi yang lebih besar sehingga tidak searah atau bernilai negatif dengan demikian, penelitian ini menolak hipotesis H1 yang menyatakan bahwa kompetensi berpengaruh terhadap kualitas auditor pada aparat Inspektorat dalam pengawasan pengelolaan keuangan daerah di kota Bitung

2. Variabel Independensi berpengaruh terhadap kualitas auditor, hal ini dapat dilihat dari tingkat signifikasi yang lebih dominan dengan demikian, penelitian ini menerima hipotesis $\mathrm{H} 2$ yang menyatakan bahwa independensi berpengaruh terhadap kualitas auditor pada aparat Inspektorat dalam pengawasan pengelolaan keuangan daerah di kota Bitung

3. Variabel Etika berpengaruh terhadap kualitas auditor, hal ini dapat dilihat dari tingkat signifikasi dengan situasi yang ada dengan demikian, penelitian ini menerima hipotesis H3 yang menyatakan bahwa etika berpengaruh terhadap kualitas auditor pada aparat Inspektorat dalam pengawasan pengelolaan keuangan daerah di kota Bitung

4. nilai $\mathrm{R}^{2}$ adalah sebesar 0,490 . Angka ini menunjukkan bahwa kualitas auditor dipengaruhi oleh faktor-faktor kompetensi, independensi dan atika sebesar $49 \%$ sedangkan sisanya sebesar $51 \%$ dijelaskan oleh factor-faktor lain atau variabel lain yang tidak diteliti dalam penelitian ini.

5. nilai $\mathrm{R}$ yang diperoleh sebesar 0,700 . Angka ini menunjukkan bahwa hubungan antara variabel bebas (X) dengan variabel terikat (Y) cukup kuat yaitu $0,70 \%$ serta angka korelasi yang dihasilkan menunjukkan angka positif $(+)$ yang berarti bahwa hubungan kedua variabel searah.

\subsection{Saran}

Saran dalam penelitian ini adalah dalam penelitian ini sangat diharapkan untuk instansi yang berkaitan, dalam hal ini Inspektorat Kota Bitung agar dapat lebih memperhatikan serta memberikan penyuluhan atau pelatihan secara berkala kepada anggota atau pegawai tentang bagaimana kualitas auditor sebagai pelaksana agar lebih bisa dipahami para pegawai yang ada guna menunjang pemerintahan yang sedang berjalan dan menunjang pengambilan keputusan serta memberikan kontribusi dan implikasi pada pengembangan akuntansi pada pemerintahan dan juga dengan penelitian yang ada agar pemerintah Kota Bitung terlebih khusus Inspektorat Kota Bitung lebih memperhatikan ketrampilan tertentu dalam suatu pengetahuan agar lebih mudah, cepat, dan tidak terjadi kesalahan yang vatal dalam pemerikasaan atau pengawasan pengelolaan keuangan daerah dalam melihat kompetensi anggota pegawai yang ada agar perkembangan kualitas auditor di bidang kompetensi lebih baik dan ada peningkatan pemahaman tentang kualitas auditor pada sektor akuntansi. Dan juga meningkatkan pendidikan profesionalnya, mempertahankan independensi dan sikap mental, mampu menggunakan kemahiran dengan cermat dan seksama, melakukan perencanaan audit dengan baik, memperoleh bukti yang cukup dan kompeten dan membuat laporan auditor sesuai kejadian yang ada.

\section{DAFTAR PUSTAKA}

Arens, A.A., J.K. Loebbecke. 2000. Auditing: An Integrated Approach. Edisi 9. New Jersey: Prentice Hall International Inc.

Afiah, Nunuy Nur. 2009. Pengaruh Kompetensi Anggota DPRD dan Kompetensi Aparatur Pemerintah Daerah terhadap Pelaksanaan Sistem Informasi Akuntansi.October 2009 Research Days. Bandung: Fakultas Ekonomi Universitas Padjadjaran. 
Arumi Savitri Fatimaningrum, Aini Mahabbati, (2006), FIP Universitas Negeri Yogyakarta, Yogyakarta.

Baswir, Revrisond, 1999. Ekonomi Kerakyatan: Amanat Konstitusi Untuk Mewujudkan Demokrasi Ekonomi di Indonesia, Penerbit: Sugeng Sarjadi, Jakarta.

Bodnar H, Hopwood Wiliam. (2006). Sistem Informasi Akuntansi, Penerbit: Andi, Yogjakarta.

Boyton C. William, Kell. G Walter dan Johnson N Raymond, 2003. Modern Auditing. Edisi Ketujuh. Jilid I Jakarta, Penerbit Erlangga.

Cahyat, A. 2004. Sistem Pengawasan terhadap Penyelenggaraan Pemerintah DaerahKabupaten Pembahasan Peraturan Perundangan di Bidang Pengawasan. Governance Brief Number 3

Darise Nurlan, 2009. Pengelolaan Keuangan Daerah, edisi 2. Penerbit PT Indeks, Jakarta.

Darise Nurlan, 2008. Pengelolaan Keuangan pada Satuan Pengelolaan Keuangan Daerah (SPKD). Penerbit PT Indeks, Jakarta.

Deis, D.R dan G.A. Groux. (1992). Determinasi Kualitas Audit Dalam Sektor Publik. The Accounting Review.

Elfarini, E.C. 2005. Pengaruh Kompetensi dan Independensi Auditor terhadap Kualitas Audit. Skripsi tidak dipublikasikan. Universitas Negeri Semarang

Firdaus A, 2005. Ikhisar Lengkap Pengantar Akuntansi, Edisi 2, Penerbit FE UI, Jakarta. FE USU, 2007

Ghozali, I. 2006. Aplikasi Analisis Multivariat dengan Program SPSS. Edisi 3. BPUndip. Semarang

Goleman, D. 2001. Working White Emotional intelligence. (terjemahan Alex Tri Kantjono W). Jakarta : PT Gramedia Pustaka Utama 